\title{
Production of transparent exopolymer particles (TEP) by the eastern oyster Crassostrea virginica
}

\author{
Michael P. McKee ${ }^{1, *}$, J. Evan Ward ${ }^{1}$, Bruce A. MacDonald ${ }^{2}$, Bridget A. Holohan ${ }^{1}$ \\ ${ }^{1}$ Department of Marine Sciences, University of Connecticut, 1080 Shennecossett Road, Groton, Connecticut 06340, USA \\ ${ }^{2}$ Department of Biology, University of New Brunswick, Saint John, PO Box 5050, New Brunswick E2L 4L5, Canada
}

\begin{abstract}
Transparent exopolymer particles (TEP) play an important role in aggregation, phytoplankton bloom dynamics and the fate of organic carbon. Various types of plankton are known to release exopolymers that contribute to the TEP pool. Little is known, however, about other potential sources of TEP and TEP precursors in the oceans, especially in nearshore waters. Suspension-feeding bivalves can form dense assemblages in coastal waters and can process large volumes of water during feeding activities (e.g. $5 \mathrm{l} \mathrm{h}^{-1} \mathrm{~g}^{-1} \mathrm{dry} \mathrm{wt}$ ). They secrete mucus to maintain clean body surfaces and to aid in capturing and transporting food material. We hypothesized that mucopolysaccharides, which are released from bivalves in dissolved or particulate form, contribute to the TEP pool. To test this hypothesis, laboratory experiments were carried out to measure the concentration of TEP and DOC in chambers with actively feeding oysters Crassostrea virginica over a $9 \mathrm{~h}$ period. Field experiments were conducted to measure TEP and DOC production by oysters in situ, using clear Plexiglas chambers on an intertidal sand-flat in New Brunswick, Canada. TEP concentrations were determined with an Alcian blue staining technique and spectrophotometric detection. DOC concentrations were determined using high-temperature catalytic oxidation (HTCO) with a platinum catalyst. Laboratory results indicated that oysters significantly enhanced TEP and DOC concentrations compared to control levels over $9 \mathrm{~h}$. Likewise, field experiments demonstrated elevated TEP concentrations in experimental chambers compared to control treatments. Our results support the hypothesis that oysters contribute to the production of TEP in coastal marine ecosystems.
\end{abstract}

KEY WORDS: Transparent exopolymer particles $\cdot$ TEP $\cdot$ Mucopolysaccharides $\cdot$ Oysters $\cdot$ Dissolved organic carbon $\cdot$ DOC $\cdot$ Aggregation

\section{INTRODUCTION}

Transparent exopolymer particles (TEP) are discrete, amorphous aggregates of mucilage that form the matrix of marine snow (Alldredge et al. 1993). The presence of TEP leads to increased coagulation efficiency, enhanced aggregation and rapid settling of particulate matter, especially during phytoplankton blooms (Dam \& Drapeau 1995). The presence of TEP has been shown to facilitate the transformation of dissolved organic carbon (DOC) into particulate organic carbon (POC) in surface waters (Passow et al. 1994), a pathway that has broad implications for our understanding of the global carbon cycle.
Numerous studies have shown that phytoplankton, such as diatoms, contribute to the production of TEP in the oceans (e.g. Alldredge et al. 1998, Passow et al. 2001, Passow 2002). Little research, however, has examined the potential contribution of larger marine organisms, particularly benthic invertebrates, to TEP production. Macrozooplankton and nekton contribute mucus material to the pelagos in the form of protective sheaths, mucus 'houses', fecal pellets, and feeding webs (Alldredge \& Silver 1988). In nearshore waters, benthic invertebrates are abundant and their potential contributions could increase aggregation and the deposition rate of suspended particles. This process could serve as a feedback mechanism, whereby the 
energy required to produce mucins is more than compensated for by the return of nutrient-rich particles to the benthos.

Many benthic invertebrates secrete mucus for a variety of applications. For example, snails and whelks secrete pedal mucus to facilitate locomotion along the benthos (Denny 1980). Corals secrete exopolymers to protect against ultraviolet damage, deter fouling organisms (Vrolijk et al. 1990), and maintain clean surfaces in turbid environments (Coffroth 1990). Suspension-feeding bivalves secrete acidic and mixed mucopolysaccharides that function in particle capture and transport on the gill and labial palps (Beninger et al. 1993). Such mucus secretions can reach the environment in a variety of ways. First, water passing over mucus-coated structures may solubilize mucopolysaccharides and carry them out the exhalent siphon or aperture in the form of dissolved organic matter (DOM). Bivalves also expel mucus and pseudofeces from the inhalant siphon or aperture during rapid valve adductions. Pseudofeces are produced by the gills and labial palps, and are composed of mucopolysaccharides and uningested particles (Ward et al. 1994, Urrutia et al. 2001). They have been shown to significantly increase aggregation and sedimentation of suspended particulates to the benthos (Davies \& Hawkins 1998), an effect that could also be attributed to the presence of TEP. Although the chemical structures of both molluscan mucus and TEP are poorly defined, the general components of both are long, branching polysaccharides covalently bonded to reactive non-carbohydrate groups such as lipids and proteins. Given the similarity in their chemical nature, we hypothesized that the release of mucus by bivalves contributes to the TEP pool.

Our working hypothesis was separated into 2 main objectives: (1) to determine if oysters produce detectable levels of TEP under controlled conditions in the laboratory, and (2) to examine the production of TEP by oysters in a natural field setting. Additionally, we were interested in determining if DOC could serve as an indicator of TEP production in bivalves. Laboratory research was designed to quantify net production of TEP and DOC by the eastern oyster Crassostrea virginica in a closed system over a $9 \mathrm{~h}$ period. Field research was designed to measure differences in TEP and DOC concentrations between control treatments and oyster populations on a subtidal sand-flat.

\section{MATERIALS AND METHODS}

Laboratory experiments. Adult oysters (7.0 to $13.5 \mathrm{~cm}$ in shell height) were collected from a nearby mariculture facility and maintained in a flow-through, seawater tank in the Rankin Laboratory at the University of Connecticut, USA. In addition to feeding on phytoplankton present in the flowing seawater, oysters received cultured and cryopreserved phytoplankton during the acclimation period. Just prior to experimentation, bivalves were cleaned with a dilute solution of freshwater and sodium hypochlorite (ca. 0.6\%) to remove fouling organisms and reduce bacterial numbers. Oysters were then maintained in filtered seawater (FSW, $0.2 \mu \mathrm{m}$ ) for $24 \mathrm{~h}$ to allow them to clear their guts and pallial cavities. Experiments that examined TEP production were conducted on 6 non-consecutive days during the year 2000. On 2 of the $6 \mathrm{~d}$ we also measured DOC concentrations. Each experiment included 3 treatments (blanks, oysters, and controls) with triplicate static chambers in each treatment. Blank chambers, each containing 31 of natural, $0.2 \mu \mathrm{m}$ FSW, were used to account for differences in ambient TEP and DOC concentrations among the $6 \mathrm{~d}$, and to account for changes in background concentrations over each $9 \mathrm{~h}$ experimental period. Experimental chambers contained 31 of FSW and 6 oysters. To stimulate a feeding response in oysters, cryopreserved phytoplankton Chaetoceros gracilis was added to each chamber. This species of diatom averages ca. $7 \mu \mathrm{m}$ in diameter and is a good food source for bivalves (Reed Mariculture). Using cryopreserved cells reduced the possible release of TEP that is associated with living phytoplankton. Control chambers, each containing 31 of FSW and cryopreserved C. gracilis, were used to account for any release of TEP or DOC from phytoplankton alone. All chambers were held in a flowing seawater table and maintained at 15 to $17^{\circ} \mathrm{C}$.

At the start of the experiment ( $t=0 \mathrm{~h}$ ), control and oyster treatments were delivered enough Chaetoceros gracilis to obtain a concentration of 10000 cells ml-1. Diatoms were again added to the experimental chambers at $t=4.5 \mathrm{~h}$, when cell concentrations were depleted, to maintain feeding activity of the oysters. Water samples were taken from all chambers at $t=0 \mathrm{~h}$ and then at $t=4.5$ and $9 \mathrm{~h}$, and analyzed for TEP, DOC, bacteria, and phytoplankton. Samples were carefully taken from the middle of each chamber using largebore syringes to avoid resuspending feces and pseudofeces. Water samples from each chamber were collected in either acid-washed, pre-ashed glass bottles fitted with teflon lids (DOC, bacteria), or clean polyethylene bottles (TEP, phytoplankton), and placed on ice in the dark until the end of the experiment. Following the experiment, oysters from each experimental chamber were labeled, frozen, and later measured to determine dry weight. All water samples were prefiltered through a $5 \mu \mathrm{m}$ Poretics PCTE filter, thereby removing phytoplankton cells that could increase clogging and post-experimental aggregation of TEP on the 
filter. Samples were then analyzed for TEP, DOC, bacteria, and phytoplankton, using the procedures outlined below.

Field experiments. Field studies were conducted on an intertidal sand-flat adjacent to the Shippegan Aquarium and Marine Station in Shippegan, New Brunswick, Canada. Adult oysters $(3.7$ to $8.1 \mathrm{~cm}$ in shell height) were collected from the sand-flat and cleaned of fouling organisms. Oysters were then placed in plastic-mesh trays and maintained subtidally on the sand-flat until used in an experiment. Experiments were conducted in situ using clear Plexiglas chambers to partially isolate groups of oysters from the surrounding water (Fig. 1). Chambers were fitted with clear plastic (Tygon) tubing attached to the head of a peristaltic pump that was maintained on shore. The peristaltic pump provided flow through the chambers at a rate of $2.51 \mathrm{~min}^{-1}$. Water was drawn in through rectangular openings in the bottom of the chamber, passed over the oysters, and then flowed out at the top of the chamber. Given the above dimensions and pumping rate, all water in the chambers was exchanged about every 4 min.

Experiments were conducted over a period of $3 \mathrm{~d}$ in August 2002. For each trial, approximately 50 oysters were placed in a plastic-mesh tray and positioned subtidally on the sand-flat. A Plexiglas chamber was placed over the tray containing the oysters and secured using guidelines and dive weights. An identical empty tray and chamber was placed next to the chamber containing oysters and served as a control. The experimental (with oysters) and control (without oysters) chambers were then connected to the pump and flow was established. After $1 \mathrm{~h}$, water samples were taken from each chamber and transported to the adjacent laboratory for preparation and analysis. We conducted 8 trials using different groups of oysters. In 2 of the trials, oysters were allowed to feed for an additional $1 \mathrm{~h}$ period, during which time the pump was not running and the oysters were exposed to a no-flow condition. Experiments were conducted during ebb, slack-low and flood tides, and seawater temperature and salinity were constant at approximately $18^{\circ} \mathrm{C}$ and $27 \mathrm{ppt}$, respectively. Water samples from each chamber were placed in appropriate containers (see above) and analyzed for TEP, DOC, bacteria, and total particulate matter using procedures outlined below. At the end of the experiments, representative oysters were haphazardly selected, shucked, and then dried to constant weight at $70^{\circ} \mathrm{C}$.

Sample analyses. Water samples from both laboratory and field experiments were analyzed using the following procedures. Phytoplankton or particle concentration in each sample was determined by means of an electronic particle counter (Coulter) and used to evaluate oyster feeding activity. Bacteria samples were sonicated to disrupt aggregates, filtered through $0.2 \mu \mathrm{m}$ black polycarbonate filters, and stained with DAPI (4', 6-diamidino-2-phenylindole dihydrochloride hydrate). Bacteria were enumerated by direct counts using an epifluorescent microscope (Porter \& Feig 1980).

TEP was quantified using a spectrophotometric method that determines concentration relative to a gum xanthan (GX) standard (Passow \& Alldredge 1995). The method calls for a $0.02 \%$ aqueous solution of Alcian blue (pH 2.5) in $0.06 \%$ acetic acid to stain the TEP. The Alcian blue was filtered through a $0.2 \mu \mathrm{m}$ Versaflow capsule prior to use (Alldredge et al. 1993). TEP samples (50 to $80 \mathrm{ml}$ ) were drawn through a $0.45 \mu \mathrm{m}$ Poretics PCTE filter at a constant, low pressure of $150 \mathrm{~mm} \mathrm{Hg}$. Material on the filter was stained with $0.5 \mathrm{ml}$ Alcian blue for less than $2 \mathrm{~s}$, after which excess dye was drawn through the filter. The filter was then rinsed with deionized water to remove unbound stain. Filters were placed in $6 \mathrm{ml}$ of $80 \% \mathrm{H}_{2} \mathrm{SO}_{4}$ for $2 \mathrm{~h}$ in order to extract the dye. Dye concentration was then quantified by determining light absorption at $787 \mathrm{~nm}$ on a spectrophotometer. TEP concentrations were then determined using a calibration factor that was calculated from the absorption curve of the GX standards. Although standard curves using GX have shown vari-

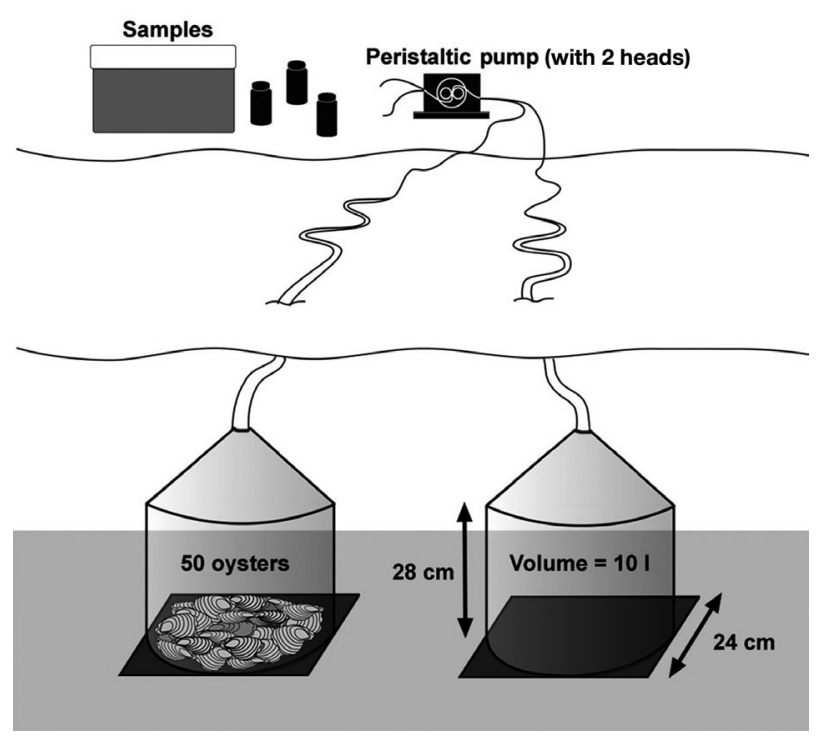

Fig. 1. Experimental set-up for field research. Each cylindrical chamber had a conical top and was $28 \mathrm{~cm}$ high and $24 \mathrm{~cm}$ in diameter, resulting in a total volume of about $10 \mathrm{l}$. The conical top was fitted with a threaded hose connector and attached to a length (ca. $18 \mathrm{~m}$ ) of clear plastic tubing (Tygon) with an inside diameter of $8 \mathrm{~mm}$. The other end of the tubing was attached to the head of a peristaltic pump that was maintained on shore. Experiments conducted using this paired design were replicated through time ( 2 to 3 trials $\mathrm{d}^{-1}$ ) over $3 \mathrm{~d}$ 
ability due to the gel-like nature of the polysaccharide substance (Hung et al. 2003), precautions were taken to create a homogeneous solution. Standard solutions were prepared with desiccated xanthan powder, mixed with an electric homogenizer, followed by ultrasonification. New standards were prepared and calibration factors were determined for each individual experiment. Nevertheless, it is important to mention that the spectrophotometric method provides a relative concentration of TEP that may differ within and among polysaccharide standards (Passow \& Alldredge 1995, Hung et al. 2003).

Analysis of non-volatile DOC was conducted using a high-temperature catalytic oxidation (HTCO) method (Shimadzu 5000 carbon analyzer with a platinum catalyst; Benner \& Strom 1993). Water samples were filtered through $0.45 \mu \mathrm{m}$ Poretics PCTE filters to remove phytoplankton cells, TEP and other particulate organic matter (POM). Samples were then acidified with hydrochloric acid $(\mathrm{pH}<4)$ and sparged with pure air for 10 min prior to analysis. Water used for instrumental blanks was processed through a reverse osmosis system and showed no detectable sign of carbon contamination. Experimental samples were quantified using two 4-point standard curves of potassium hydrogen phthalate, ranging from 0 to 0.5 and 0 to $2.5 \mathrm{mg} \mathrm{Cl}^{-1}$.

Statistical analyses. In laboratory experiments, blank treatments (no oysters, no diatoms) were used to (1) monitor potential changes in TEP and DOC due to bacteria and/or physical processes over the $9 \mathrm{~h}$ experimental period, and (2) account for natural differences in background concentrations of TEP and DOC among experimental days. Statistical analysis of blank treatments using a 1-way repeated measures analysis of venance (ANOVAR) indicated that on 1 of the 6 experimental days (October 12, 2000) there was a significant increase in TEP over time $(\mathrm{p}<0.05)$. Therefore, data from this date were removed from further analysis. In addition, a 2-way ANOVAR indicated that there were significant differences in TEP and DOC concentrations in blank chambers among experimental days $(\mathrm{p}<$ 0.05). Therefore, prior to statistical analyses, TEP and DOC data from each experiment were normalized for background concentrations by subtracting the blank concentrations for their respective day. A nested, repeated-measures ANOVAR was then used to examine differences and changes in TEP and DOC concentrations in control and oyster treatments, with time as the repeated factor, treatment as an independent variable, and experimental date nested within treatment (Zar 1984). Data were log-transformed and analyzed for normality and homogeneity of variance by evaluating the degree of kurtosis and Greenhouse and Geiser's epsilon index, respectively (for repeated mea- sures; LaTour \& Miniard 1983, Systat 9 1999). Data were further analyzed by means of a posteriori contrast matrices in order to determine differences between treatments within a given time (Systat 9 1999). If the model detected significant differences with time, then treatments were separated and analyzed using a 1way ANOVAR. Bacterial numbers from laboratory experiments were also analyzed using a 2-way ANOVAR.

Field experiments were designed to examine differences in TEP and DOC concentrations between treatments, so data were analyzed using a 1-tailed, paired $t$-test. We used a 1-tailed procedure because of the $a$ priori assumption that TEP and DOC levels would be higher in experimental chambers compared to control chambers. A 2-tailed, paired $t$-test was used to compare bacterial numbers in experimental and control chambers because there was no a priori assumption that bacterial concentrations would be higher or lower in chambers with oysters (Zar 1984). Normality of the differences between pairs was analyzed by evaluating the degree of kurtosis (Systat 9 1999). Variability around the means of laboratory and field data is expressed as standard error (SE) of the mean. For all comparisons, an alpha level of 0.05 was used.

\section{RESULTS}

\section{Laboratory experiments}

In nearly all experiments, more than half of the oysters showed signs of feeding after $20 \mathrm{~min}$, and all were actively feeding within the first hour. Oysters typically removed $90 \%$ of the phytoplankton in experimental chambers within the first hour of feeding. After depleting the phytoplankton, oysters appeared less active, periodically opening and closing their valves during the experiment. The average dry tissue mass of oysters used in all laboratory experiments was $1.33 \pm 0.1 \mathrm{~g}$ $(\mathrm{n}=102)$.

The concentration of bacteria was low relative to natural seawater due to filtration of water prior to the experiments $\left(1.16 \times 10^{5} \pm 0.07\right.$ cells ml ${ }^{-1}$, both treatments and times combined). There was no significant difference in the number of bacteria between control and oyster chambers, nor did numbers significantly increase over the $9 \mathrm{~h}$ experimental period $(\mathrm{p}>0.05$, ANOVAR; Table 1). These results suggest that any effects of bacteria on TEP and DOC concentrations during the trials were equal in the experimental and control chambers.

The mean background concentration of TEP in blank treatments during the 5 experimental days was $114 \pm$ $7 \mu \mathrm{g} \mathrm{TEP}^{-1}$ and there was no statistical increase in 
Table 1. Crassostrea virginica. Results of laboratory experiments showing data for concentration of transparent exopolymer particles (TEP, gum xanthan equivalents) and concentration of dissolved organic carbon (DOC) in all treatments, and concentration of bacteria (Bact) in control and oyster chambers. For statistical analysis, background levels (blanks) have been subtracted from TEP and DOC concentrations. Oyster treatments displayed a significant increase in TEP concentration over the experimental period $\left({ }^{*} \mathrm{p}<0.01\right.$, ANOVAR), and TEP and DOC concentrations were significantly higher in oyster chambers than in control chambers at $9 \mathrm{~h}\left({ }^{* *} \mathrm{p}<0.05\right.$, ANOVAR). Data are means \pm SE. nd: no data

\begin{tabular}{|c|c|c|c|}
\hline \multirow{2}{*}{$\begin{array}{l}\text { Data type } \\
\text { Treatment }\end{array}$} & \multicolumn{3}{|c|}{ Time (h) } \\
\hline & 0 & 4.5 & 9 \\
\hline \multicolumn{4}{|l|}{$\operatorname{TEP}\left(\mu \mathrm{g} \mathrm{l}^{-1}\right)$} \\
\hline Blank (n = 15) & $112 \pm 11$ & $127 \pm 13$ & $101 \pm 11$ \\
\hline Control $(n=15)$ & $103 \pm 11$ & $143 \pm 12$ & $130 \pm 21$ \\
\hline Oyster $(\mathrm{n}=17)$ & $147 \pm 12$ & $145 \pm 9$ & $231 \pm 28^{*, * *}$ \\
\hline \multicolumn{4}{|l|}{$\operatorname{DOC}\left(\mathrm{mg} \mathrm{l}^{-1}\right)$} \\
\hline Blank $(\mathrm{n}=6)$ & $0.90 \pm 0.2$ & $1.02 \pm 0.1$ & $1.26 \pm 0.0$ \\
\hline Control $(n=6)$ & $1.44 \pm 0.3$ & $1.43 \pm 0.3$ & $1.32 \pm 0.2$ \\
\hline Oyster $(n=6)$ & $1.57 \pm 0.2$ & $1.83 \pm 0.2$ & $2.14 \pm 0.4^{* *}$ \\
\hline \multicolumn{4}{|c|}{ Bact (cells ml $\mathbf{m}^{-1}$ ) } \\
\hline Control $(n=7)$ & $1.15 \pm 0.1 \times 10^{5}$ & nd & $1.37 \pm 0.1 \times 10^{5}$ \\
\hline Oyster $(n=7)$ & $1.14 \pm 0.1 \times 10^{5}$ & nd & $1.21 \pm 0.1 \times 10^{5}$ \\
\hline
\end{tabular}

concentration over the $9 \mathrm{~h}$ experimental period $(\mathrm{p}>$ 0.05, ANOVAR). Mean TEP concentrations in the blank, control and oyster treatments, prior to the subtraction of background levels, are given in Table 1. Statistical analysis was performed on TEP concentrations in the control and oyster treatments after the blanks had been subtracted for each experimental day. Results of the nested ANOVAR indicated that there was a significant effect of both treatment and time on TEP concentration ( $p<0.01$; Fig. 2). There was also a significant interaction effect between these 2 factors ( $p<0.05$; Table 2), indicating that the effect of time on TEP production varied among treatments. A posteriori contrasts indicated that concentration of TEP in oyster treatments differed significantly from controls at $9 \mathrm{~h}$ ( $p<0.01$ ), but not at 4.5 or $0 \mathrm{~h}$ ( $\mathrm{p}>0.05$, Table 2$)$. Further analysis with 1-way ANOVAR indicated a significant increase in TEP production with time in the oyster treatments $(p<0.001)$, and no significant change with time in control treatments ( $p>0.05$, Fig. 2). Mean difference in TEP concentration between the oyster and control chambers at $9 \mathrm{~h}$ was $97 \pm 22 \mu \mathrm{g}$ TEP $\mathrm{l}^{-1}$. Dividing this difference by the average volume-specific dry tissue mass of oysters $\left(\mathrm{g} \mathrm{l}^{-1}\right)$ used in the experiments gives a biomass-specific production of $47 \pm 14 \mu \mathrm{g}$ TEP $\mathrm{g}^{-1}$ dry wt over the experimental period.

The mean background concentration of DOC in the blank treatments during the 2 experimental days was $0.91 \pm 0.1 \mathrm{mg} \mathrm{C}^{-1}$ and there was no statistical increase in concentration over the $9 \mathrm{~h}$ experimental period $(\mathrm{p}>$ 0.05, ANOVAR). Mean DOC concentrations in the blank, control and oyster treatments, prior to the subtraction of background levels, are given in Table 1. Statistical analysis was performed on DOC concentrations in the control and the oyster treatments after the blanks had been subtracted for each experimental day. Results of the nested ANOVAR indicated a significant effect of treatment $(p<0.01)$, but not time $(p=0.06)$ on DOC concentration (Fig. 2). There was no significant interaction effect between these 2 factors $(p=0.10)$. A posteriori contrasts indicated that concentration of DOC in the oyster treatments differed significantly from controls at $9 \mathrm{~h}(\mathrm{p}<0.01)$, but not at 4.5 or $0 \mathrm{~h}(\mathrm{p}>$ 0.05, Table 3). Further analysis with 1-way ANOVAR detected no significant increase in DOC production with time in the oyster or control treatments $(p>0.05$, Fig. 2). The mean difference in DOC concentration between the oyster and control chambers at $t=9$ was $0.82 \pm 0.1 \mathrm{mg} \mathrm{C} \mathrm{l}^{-1}$. Dividing this difference by the
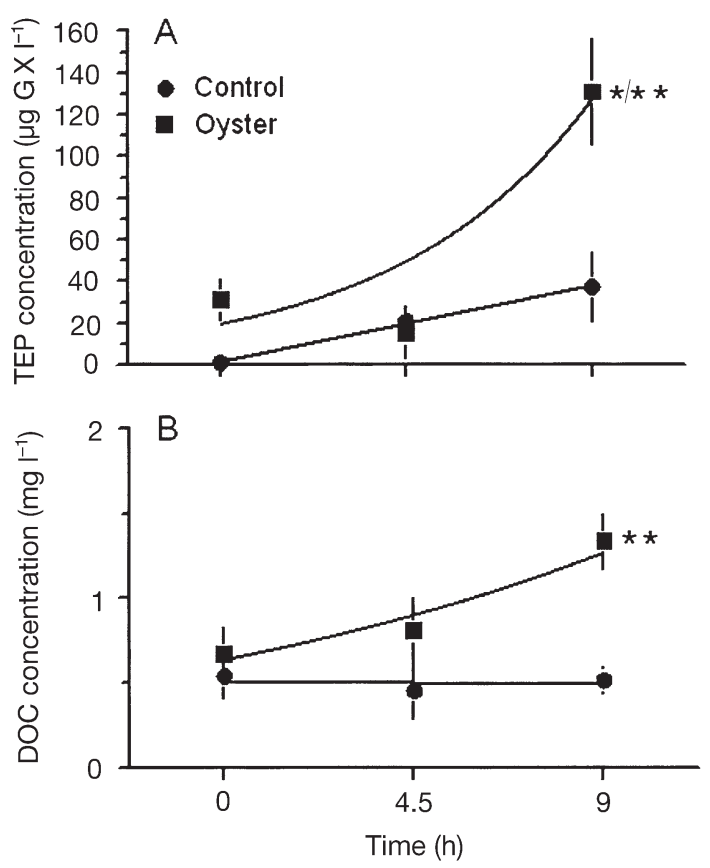

Fig. 2. Crassostrea virginica. Results of laboratory experiments, showing mean concentrations of (A) transparent expolymer particles (TEP) and (B) dissolved organic carbon (DOC) above background levels (blanks). Control treatments did not display significant change in TEP and DOC concentration during the experiment. Oyster treatments exhibit significant increase in TEP concentration over a $9 \mathrm{~h}$ period $(* \mathrm{p}<$ 0.01 , ANOVAR), yet no significant increase in DOC concentration. In addition, TEP and DOC concentration in oyster chambers was significantly higher than in control chambers at $9 \mathrm{~h}(* * \mathrm{p}<0.05$, ANOVAR). No differences between treatments were found at other time intervals. Lines indicate data trends; error bars represent standard error of means (TEP, $\mathrm{n}=17$; DOC, $\mathrm{n}=6$ ). GX: gum xanthan 
Table 2. Crassostrea virginica. (A) Repeated-measures, nested analysis of variance and (B) a posteriori contrasts for log-transformed data comparing transparent expolymer particle (TEP) concentrations between control and oyster treatments. Date of experiments was nested within treatment (Date). TEP concentration was determined at 3 times: 0, 4.5, and $9 \mathrm{~h}$ after each trial began. G: probabilities adjusted for Greenhouse-Geisser epsilon $(=0.781) ;{ }^{*}$ significant at alpha level of 0.05

\begin{tabular}{|c|c|c|c|c|c|}
\hline $\begin{array}{l}\text { (A) ANOVAR } \\
\text { Source }\end{array}$ & df & MS & $F$ & $\mathrm{p}$ & Corrected $\mathrm{p}$ \\
\hline \multicolumn{6}{|l|}{ Between subjects } \\
\hline Treatment & 1 & 0.348 & 10.48 & $0.004^{*}$ & \\
\hline (Date) & 8 & 0.072 & 2.16 & 0.075 & \\
\hline Error & 21 & 0.033 & & & \\
\hline \multicolumn{6}{|l|}{ Within subjects } \\
\hline Time & 2 & 0.215 & 5.38 & $0.008^{*}$ & $0.015(\mathrm{G})^{*}$ \\
\hline Time $\times$ Treatment & 2 & 0.206 & 5.16 & $0.010^{*}$ & $0.017(\mathrm{G})^{*}$ \\
\hline Time × (Date) & 16 & 0.044 & 1.10 & 0.383 & $0.390(\mathrm{G})$ \\
\hline Error & 42 & 0.040 & & & \\
\hline \multicolumn{6}{|c|}{ (B) A posteriori, univariate contrasts between treatments } \\
\hline Effect & df & MS & F & $\mathrm{p}$ & \\
\hline Time 0 & 1 & 0.092 & 3.24 & 0.109 & \\
\hline Error & 8 & 0.028 & & & \\
\hline Time 4.5 & 1 & 0.009 & 0.23 & 0.644 & \\
\hline Error & 8 & 0.039 & & & \\
\hline Time 9 & 1 & 0.659 & 7.10 & $0.029^{*}$ & \\
\hline Error & 8 & 0.093 & & & \\
\hline
\end{tabular}

between the oyster and control chambers ( $\mathrm{p}>0.05$, paired $t$-test; Table 4 ). This result suggests that any effects of bacteria on TEP and DOC concentrations during the trials were equal in experimental and control chambers.

TEP concentrations in the control and oyster chambers ranged from 324 to 1067 and 452 to $1488 \mu \mathrm{g}$ TEP $\mathrm{l}^{-1}$, respectively. Seawater from the oyster chambers had a significantly higher concentration of TEP than seawater from the control chambers after the experimental period ( $\mathrm{p}<0.05$, paired $t$ test; Table 4). This result indicates that the feeding activity of oysters, in their natural setting, produced measurable levels of TEP. The mean difference in TEP concentration between the oyster chambers and their paired control chambers was $129 \pm 61 \mu \mathrm{g}$ TEP $\mathrm{l}^{-1}$. Dividing this difference by the average volume-specific dry tissue mass of oysters $\left(\mathrm{g} \mathrm{l}^{-1}\right)$ used in the experiments gives a biomass-specific production of $34 \pm 16 \mu \mathrm{g}$ TEP $\mathrm{g}^{-1}$ dry wt over the experimental period. average volume-specific dry tissue mass of oysters $\left(\mathrm{g} \mathrm{l}^{-1}\right)$ used in the experiments gives a biomass-specific production of $0.51 \pm 0.2 \mathrm{mg} \mathrm{C} \mathrm{g}^{-1}$ dry wt over the experimental period.

\section{Field experiments}

Observations of oysters in the experimental chambers indicated that many were open and apparently feeding during the trials. Periodic counts of the number of particles in the oyster and control chambers supported these observations. On average, particle concentrations were $30 \%$ lower in water from the oyster chambers compared to water from the control chambers. Randomly sampled oysters used in field trials averaged $0.75 \pm 0.03 \mathrm{~g}$ dry tissue mass $(n=30)$.

Bacterial concentrations averaged $1.71 \times 10^{6}$ cells ml ${ }^{-1}$ in the control cham-

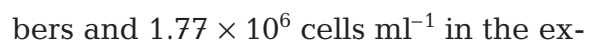
perimental chambers. There was no significant difference in bacterial numbers
Table 3. Crassostrea virginica. (A) Repeated-measures, nested analysis of variance and (B) a posteriori contrasts for log-transformed data comparing dissolved organic carbon (DOC) concentrations between control and oyster treatments. Date of experiments was nested within treatment (Date). TEP concentration was determined at 3 times: 0, 4.5, and $9 \mathrm{~h}$ after each trial began. G: probabilities adjusted for Greenhouse-Geisser epsilon $(=0.781)_{i}{ }^{*}$ : significant at alpha level of 0.05

\begin{tabular}{|c|c|c|c|c|c|}
\hline $\begin{array}{l}\text { (A) ANOVAR } \\
\text { Source }\end{array}$ & df & MS & $F$ & $\mathrm{p}$ & Corrected $\mathrm{p}$ \\
\hline \multicolumn{6}{|l|}{ Between subjects } \\
\hline Treatment & 1 & 0.097 & 17.56 & $0.003^{*}$ & \\
\hline (Date) & 2 & 0.053 & 9.59 & $0.008^{*}$ & \\
\hline Error & 8 & 0.006 & & & \\
\hline \multicolumn{6}{|l|}{ Within subjects } \\
\hline Time & 2 & 0.023 & 3.38 & 0.060 & $0.060(\mathrm{G})$ \\
\hline Time $\times$ Treatment & 2 & 0.018 & 2.70 & 0.098 & $0.099(\mathrm{G})$ \\
\hline Time $\times($ Date $)$ & 4 & 0.013 & 1.93 & 0.154 & $0.155(\mathrm{G})$ \\
\hline Error & 16 & 0.007 & & & \\
\hline \multicolumn{6}{|c|}{ (B) A posteriori, univariate contrasts between treatments } \\
\hline Effect & $\mathrm{df}$ & MS & $F$ & $\mathrm{p}$ & \\
\hline Time 0 & 1 & 0.003 & 0.36 & 0.564 & \\
\hline Error & 8 & 0.008 & & & \\
\hline Time 4.5 & 1 & 0.026 & 3.38 & 0.103 & \\
\hline Error & 8 & 0.008 & & & \\
\hline Time 9 & 1 & 0.103 & 37.09 & $0.000^{*}$ & \\
\hline Error & 8 & 0.003 & & & \\
\hline
\end{tabular}


Table 4. Crassostrea virginica. Results of field experiments showing data for concentration of transparent exopolymer particles (TEP, gum xanthan equivalents), concentration of dissolved organic carbon (DOC), and concentration of bacteria (Bact) in control and oyster chambers. Significant changes between control and oysters chambers are indicated and were determined using paired $t$-tests. Data are means $\pm \mathrm{SE}$. ns: not significant at $p>0.05$

\begin{tabular}{|c|c|c|c|}
\hline \multirow[t]{2}{*}{ Data type } & \multicolumn{2}{|c|}{ Treatment } & \multirow[t]{2}{*}{ Significance } \\
\hline & Control & Oyster & \\
\hline $\begin{array}{c}\operatorname{TEP}\left(\boldsymbol{\mu} \mathbf{g ~}^{\mathbf{- 1}}\right) \\
\quad(\mathrm{n}=10)\end{array}$ & $741 \pm 100$ & $869 \pm 100$ & $\mathrm{p}<0.05$ \\
\hline $\begin{array}{c}\text { DOC }\left(\mathbf{m g ~ l}^{-\mathbf{1}}\right) \\
(\mathrm{n}=8)\end{array}$ & $3.89 \pm 0.4$ & $4.09 \pm 0.5$ & ns \\
\hline $\begin{array}{c}\text { Bact (cells } \mathbf{~ m l}^{-\mathbf{1}} \text { ) } \\
\quad(\mathrm{n}=8)\end{array}$ & $1.71 \pm 0.2 \times 10^{6}$ & $1.77 \pm 0.2 \times 10^{6}$ & ns \\
\hline
\end{tabular}

DOC concentrations in the control and oyster chambers ranged from 2.3 to 5.0 and 2.3 to $6.7 \mathrm{mg} \mathrm{C}^{-1}$, respectively. No significant difference was found in DOC levels between the control and oyster chambers ( $\mathrm{p}>0.05$, paired $t$-test; Table 4 ).

\section{DISCUSSION}

Our laboratory research shows that oysters significantly enhance TEP concentrations in seawater over a $9 \mathrm{~h}$ period. Concentrations in the oyster treatments were nearly double that of control treatments (Table 1), suggesting that mucins released by oysters enhance the TEP signal. Furthermore, no statistical increase occurred in the control chambers over the same period (Fig. 2). The slight increase in TEP levels in the control treatments, illustrated by the trend line in Fig. 2, was probably due to the higher diatom concentrations in these chambers compared to chambers with actively feeding oysters at $9 \mathrm{~h}$. Although we used cryopreserved phytoplankton to minimize TEP production, some exopolymers may have diffused from the non-living cells over time. The measured increase in TEP concentration in the oyster treatments should be considered net production as it may have underestimated actual gross production due to 2 conditions of our experimental design: (1) Oysters are capable of retaining particles as small as $2 \mu \mathrm{m}$ in diameter with 50 \% efficiency (Møhlenberg \& Riisgård 1978, Riisgård 1988). TEP ranges in size from $0.45 \mu \mathrm{m}$ to several hundred micrometers (Alldredge et al. 1993), becoming larger under conditions of potential aggregation. In a closed chamber, oysters could have removed small, actively forming TEP while the experiments were underway. (2) Water samples were prefiltered through a $5 \mu \mathrm{m}$ filter prior to analysis to remove phytoplankton cells and reduce their contribution to the TEP signal. This action may have also reduced the concentration of TEP produced by oysters. Future laboratory experiments should be conducted in a flow-through system in order to determine gross production rates.

Similarly, on an intertidal sand-flat, the presence of oysters significantly increased the TEP concentration of water flowing through the experimental chamber. Elevated TEP concentrations in the experimental chambers were probably due to feeding activity and release of mucins by oysters. Overall, oyster activity enhanced the TEP concentration by about $17 \%$ compared to control chambers, which represented conditions of the surrounding water. Interestingly, the biomass-specific production of TEP by oysters in the field and the laboratory were strikingly similar (field: $34 \pm$ $16 \mu \mathrm{g}$ TEP g ${ }^{-1}$ dry wt; laboratory: $47 \pm 14 \mu \mathrm{g}$ TEP g ${ }^{-1}$ dry wt). Although comparable, a simple association is complicated by the differing dynamics of the field and laboratory experimental conditions (static versus flowing), as well as the different time frames over which experiments were conducted. The field results are perhaps the best estimate of the TEP production potential by oysters as they were obtained under more natural conditions. In control chambers, the concentration of TEP measured in the field was about 20 times higher than concentrations measured in the laboratory (at $t=$ $9 \mathrm{~h}$, cf. Tables $1 \& 4$ ). This is not surprising given the extensive prefiltration of water in laboratory experiments. In addition, TEP levels measured at our field site (Shippegan, New Brunswick) were 3 to 4 times higher than TEP concentrations measured in Monterey Bay during a mid-summer Chaetoceros gracilis bloom $\left(271 \pm 30[\mathrm{SD}] \mu \mathrm{g}\right.$ TEP ${ }^{-1}$; Passow \& Alldredge 1995). The higher levels of TEP measured at our site were probably due to several factors. Field experiments were conducted on an inshore sand-flat where water level ranged from about 0.3 to $1.7 \mathrm{~m}$ with each tidal cycle. The areas around our site supported large populations of oysters and other suspension-feeders as well as extensive beds of seagrass. Rafts of seagrass blades routinely floated by our sampling chambers carried by the ebb and flow of the tide. Seagrasses are known to produce DOM (Alber \& Valiela 1994), which may have resulted in elevated TEP levels at our study site. Nevertheless, oyster-feeding activity produced a detectable increase in TEP concentration above these high background levels. As both the laboratory and field experiments suggest, oysters may contribute significantly to the local TEP pool.

In laboratory experiments, changes in DOC concentrations in control and oyster treatments mirrored changes in TEP concentrations. There was a clear trend of increasing DOC concentrations in oyster treatments over time, and mean DOC concentration was 
significantly higher in the oyster treatments compared to controls at $9 \mathrm{~h}$ (Fig. 2, Table 1). Bivalves have previously been shown to produce measurable amounts of DOC (Famme \& Knudsen 1983). The release of soluble mucopolysaccharides, which energetically can amount to ca. $40 \%$ of the total production of some molluscs (Bayne \& Newell 1983), was probably the major source of this organic carbon. Although feces can contribute to the DOC pool, little was produced during our laboratory experiments. In addition, bivalves are ammonotelic, so little if any organic carbon is associated with excretion (Bayne \& Newell 1983, Hawkins \& Bayne 1992). In the field experiments, there was no significant difference in DOC concentrations between the experimental and control chambers. An abundance of macrophytic material could explain the elevated DOC concentrations in comparison to another field study in the Gulf of Mexico (0.24 to $0.58 \mathrm{mg} \mathrm{C} \mathrm{l}^{-1}$; Hung et al. 2001) and bacterial decomposition of POM could account for a low signal-to-noise ratio of DOC. Concentrations of DOC in laboratory experiments more closely resembled those of the aforementioned field studies in the Gulf of Mexico. In the laboratory, precautions were made to remove existing POM from the water using filtration prior to experimentation. Although we did not measure a significant increase in DOC concentrations over time, the oyster treatments showed higher concentrations than control treatments at $9 \mathrm{~h}$. Under controlled conditions, DOC levels may be indicative of TEP precursors but, due to other potential sources of DOC in the field, production of solubilized mucopolysaccharides by bivalves is not a robust indicator of TEP production.

Although bacteria are known to produce exopolymers (Decho 1990), no studies have shown that bacteria contribute directly to the TEP pool (Passow et al. 2001, Passow 2002). The role of bacteria in DOC production and utilization remains unclear at this point in time. Bacteria will most probably utilize labile DOC and convert it into refractory DOC (Ogawa et al. 2001). This may change the surface-active nature of dissolved TEP precursors and reduce the likelihood for aggregation. However, bacterial biomass remained low and constant in the control and oyster treatments in both the laboratory and field experiments (Tables $1 \& 4$ ). These data suggest that bacterial numbers alone cannot explain the differences in TEP and DOC concentrations over time or among control and oyster treatments.

In conclusion, this research is the first to investigate the release of TEP by the eastern oyster Crassostrea virginica, and supports the hypothesis that oysters produce TEP that may contribute to organic aggregates in coastal waters. The presence of TEP in surface waters has been shown to enhance particle aggregation and increase the settling rate of POM (Dam \& Drapeau
1995, Davies \& Hawkins 1998). Therefore, in areas that support large populations of oysters, elevated levels of TEP might increase the deposition rate of organic-rich particles, thereby enhancing benthic-pelagic coupling and the flux of food to the benthos. Our results highlight the role of oysters in the production of TEP, and suggest that oysters and other bivalves may influence the aggregation rate of POM in coastal waters. Future research is necessary to evaluate the net production of TEP in the field and assess the overall contribution of bivalves and other benthic invertebrates to the TEP pool.

Acknowledgements. We would like to thank K. Murphy for assisting in laboratory preparation and experimentation, and G. Rivara (Cornell Cooperative Extension) for the supply of Crassostrea virginica. We also express our gratitude to J. Brookes, R. and P. Rioux, and the staff of the Shippagan Aquarium and Marine Centre for assisting with our fieldwork in New Brunswick. This research was funded by grants from the National Science Foundation to J.E.W. (OCE 981-8479, OCE/Career 987-5068, DBI-FSML 990-7701), and the Natural Sciences and Engineering Research Council of Canada (NSERC) to B.A.M.

\section{LITERATURE CITED}

Alber M, Valiela I (1994) Production of microbial organic aggregates from macrophyte-derived dissolved organic material. Limnol Oceanogr 39:37-50

Alldredge AL, Silver MW (1988) Characteristics, dynamics and significance of marine snow. Prog Oceanogr 20:41-82

Alldredge AL, Passow U, Logan BE (1993) The abundance and significance of a class of large, transparent organic particles in the ocean. Deep-Sea Res 40:1131-1140

Alldredge AL, Passow U, Haddock SHD (1998) The characteristics and transparent exopolymer (TEP) content of marine snow formed from thecate dinoflagellates. J Plankton Res 20:393-406

Bayne BL, Newell RC (1983) Physiological energetics of marine molluscs. In: Saleuddin ASM, Wilbur KM (eds) The Mollusca, Vol 4, physiology Part 1. Academic Press, New York, p 407-515

Beninger PG, St-Jean S, Poussart Y, Ward JE (1993) Gill function and mucocyte distribution in Placopecten magellanicus and Mytilus edulis (Mollusca: Bivalvia): the role of mucus in particle transport. Mar Ecol Prog Ser 98: $275-282$

Benner R, Strom M (1993) A critical evaluation of the analytical blank associated with DOC measurements by hightemperature catalytic oxidation. Mar Chem 41:153-160

Coffroth MA (1990) Mucous sheet formation on poritid corals: an evaluation of coral mucus as a nutrient source on reefs. Mar Biol 105:39-49

Dam HG, Drapeau DT (1995) Coagulation efficiency, organicmatter glues and the dynamics of particles during a phytoplankton bloom in a mesocosm study. Deep-Sea Res 42: 111-123

Davies MS, Hawkins SJ (1998) Mucus from marine mollusks. In: Blaxter JHS, Southward AJ, Tyler PA (eds) Advances in marine biology, Vol 34. Academic Press. San Diego, CA, p 1-71 
Decho AW (1990) Microbial exopolymer secretions in ocean environments: their role(s) in food webs and marine processes. Oceanogr Mar Biol Annu Rev 28:75-153

Denny MW (1980) The role of gastropod pedal mucus in locomotion. Nature 285:160-161

Famme P, Knudsen J (1983) Transitory activation of metabolism, carbon dioxide production and release of dissolved organic carbon by the mussel Mytilus edulis L., following periods of self-induced anaerobiosis. Mar Biol Lett 4: 183-192

Hawkins AJS, Bayne BL (1992) Physiological interrelations, and the regulation of production. In: Gosling E (ed) The mussel Mytilus: ecology, physiology, genetics and culture. Developments in Aquaculture and Fisheries Science, Vol 25. Elsevier, New York, p 171-222

Hung C, Tang D, Warnken KW, Santschi PH (2001) Distributions of carbohydrates, including uronic acids, in estuarine waters of Galveston Bay. Mar Chem 73:305-318

Hung C, Laodong G, Santschi PH, Alvarado-Quiroz N, Haye JM (2003) Distributions of carbohydrate species in the Gulf of Mexico. Mar Chem 81:199-135

LaTour SA, Miniard PW (1983) The misuse of repeated measures analysis in marketing research. J Marketing Res 20: 45-57

Møhlenberg F, Riisgård HU (1978) Efficiency of particle retention in 13 species of suspension feeding bivalves. Ophelia 17:239-246

Ogawa H, Amagai Y, Koike I, Kaiser K, Benner R (2001) Production of refractory dissolved organic matter by bacteria. Science 292:917-920

Passow U (2002) Production of transparent exopolymer parti-

Editorial responsibility: Kenneth Tenore (Contributing Editor), Solomons, Maryland, USA cles (TEP) by phyto- and bacterioplankton. Mar Ecol Prog Ser 236:1-12

Passow U, Alldredge AL (1995) A dye-binding assay for the spectrophotometric measurement of transparent exopolymer particles (TEP). Limnol Oceanogr 40:1326-1335

Passow U, Alldredge AL, Logan BL (1994) The role of particulate carbohydrate exudates in the flocculation of diatom blooms. Deep-Sea Res 41:335-357

Passow U, Shipe RF, Murray A, Pak DK, Brzezinski MA, Alldredge AL (2001) The origin of transparent exopolymer particles (TEP) and their role in the sedimentation of particulate matter. Cont Shelf Res 21:327-346

Porter KG, Feig YS (1980) The use of DAPI for identifying and counting aquatic microflora. Limnol Oceanogr 25:943-948

Riisgård HU (1988) Efficiency of particle retention and filtration rate in 6 species of Northeast American bivalves. Mar Ecol Prog Ser 45:217-223

Systat 9 (1999) Statistics I. SPSS, Chicago, IL

Urrutia MB, Navarro E, Ibarrola I, Iglesias JIP (2001) Preingestive selection processes in the cockle Cerastoderma edule: mucus production related to rejection of pseudofaeces. Mar Ecol Prog Ser 209:177-187

Vrolijk NH, Target NM, Baier RE, Meyer AE (1990) Surface characterization of two gorgonian coral species: implications for a natural antifouling defense. Biofouling 2:39-54

Ward JE, Newell RIE, Thompson RJ, MacDonald BA (1994) In vivo studies of suspension-feeding processes in the eastern oyster, Crassostrea virginica (Gmelin). Biol Bull (Woods Hole) 186:221-240

Zar JH (1984) Biostatistical analysis, 2nd edn. Prentice-Hall, Englewood Cliffs, NJ

Submitted: September 2, 2003; Accepted: September 10, 2004 Proofs received from author(s): February 17, 2005 